\title{
CREDIT INDEBTEDNESS AS CONVERGENCE CATALYST OF ECONOMIC REGENERATION IN THE V4 COUNTRIES
}

\author{
Martin Hudec ${ }^{1}$
}

\begin{abstract}
Financial institutions perform an important role as financial intermediaries in the financial market of the Visegrad group of four countries. These institutions ensure the smooth transfer and redistribution of funds from the various economic players with surplus savings to those who need freely obtainable funds through loans. This transfer and redistribution essentially accelerates the convergence of the four countries economics, through creating consumer debt closer to that of the developed and competitive western economies. The purpose of this paper is to research available statistics to evaluate and compare different aspects, conditions, and development of consumer credits in these four countries in terms of their progress with economic recovery, as a part of convergence after the crisis period, in Central Europe.
\end{abstract}

JEL Classification Numbers: D51, O4, O16, DOI: http://dx.doi.org/10.12955/cbup.v4.758

Keywords: consumer credit development, economic growth, financial market, Visegrad group.

\section{Introduction}

Financial institutions represent financial intermediaries, as a basic part of the financial system and market, whose main task is to facilitate the movement of funds between various economic players. In this case, an offer of available financial resource, in the form of savings for various economic players, meets demand for funds to use as investments. For efficient operation and use of the banking system in the four countries of the Visegrad group (V4), it is vital that the group's markets have a sufficient number of economic players willing to entrust their savings in the banks as well as a sufficient number of players willing to rely on the financial system in the event of money shortage.

Furthermore, financial institutions, such as banks, allocate and redistribute the surpluses (savings) of the economic players, embodied in the structure of loans, to those who have a demand for available funds to finance their investment plans. Institutions that provide financial services play an important role in restoring and sustaining economic growth in the V4 countries by maintaining the balance between risk, return, and liquidity over time. Central banks in those countries control the money supply, whereas the commercial banks ensure the flow of funds between different economic players, establishing a relationship that results in market stability and further potential growth, depending on the level of sustainable indebtedness (Bruun, 2014). Credit means a certain value of financial funds provided with agreed conditions involving future repayments, and usually within a specified time. Loans and other forms of financing are most important for commercial banks and are considered in resolving disputes; providing temporary surplus funds for certain economic players and temporary shortages for others (Mishkin, Giuliodori, \& Matthews, 2013).

Loans are considered in many developed economies a traditional source of financing, with negotiations between the company, country, and banks serving as a qualitative transformation of money; that is, converting money in savings into money for investments, through which occurs a huge acceleration of economic growth. Nevertheless, loans are often high risk acquisitions due to possible unforeseen changes in the economic cycles, especially in developing economies.

Loans lead to diversion of funds from the lender to the borrower; the condition being that the debtor will return the loaned funds on time and with interest. The creditor is an economic player with a surplus of funds to offer, while the borrower represents one that requires such funds. Through customer loans, individual debt is created to financially accelerate and fulfill a borrower's financial needs, as a tool of overcoming a temporary lack of resources. An exchange occurs with fulfilment of the loan requirements. Consumer credit, through loans, is provided to customers for their financial needs, such as the purchase of consumer goods, and is a common way of obtaining funds from banking or non-banking institutions.

\footnotetext{
${ }^{1}$ Martin Hudec, University of Economics in Bratislava, Faculty of Commerce, Department of Marketing, Dolnozemská cesta 1/A, 85235 Bratislava 5, Slovak Republic, mhudec18@gmail.com
} 


\section{Methodology}

This scientific research was based on available theoretical and empirical knowledge presented as quantitative statistics that form part of econometric methods and models in existent economic applications. From this data, this research evaluated, compared, and outlined different aspects, conditions, and development of consumer credits in the V4 countries to assess their progress within the desired economic recovery, as a part of the convergence affected by the financial crisis.

\section{Results and Discussion}

The Importance of Customer Credit

This part of the research was devoted to the financial market regarding customer credit, i.e., loans offered by the financial institutions of the V4 countries that focus on their development and credit indebtedness. Banks and other financial institutions in the V4 countries show increased interest in working with individuals, as well as with businesses, in lending within the current highly competitive environment. Their goal is to understand client needs and create tailor-made products and services to finance these needs so that the clients commit to the banking establishment in long-term cooperation for as long as possible. Lending is the most effective and profitable way for financial institutions to succeed. However, profiting in this way is affected by net interest income. Evaluating interest rate policy of banks in the Visegrad group requires insight into the development of interest rates in the V4 markets compared with that in the international market, which are the reference rates that are derived from interest rates of bank loans. The income from interest is essential for financial institutions to cover losses, while the expenses incurred with the interest reflect the cost of borrowed funds (deposits). Commercial banks in the V4 countries ensure the interest rate policy allows for optimum balance between interest income and expense. Moreover, it should allow them to raise funds in the form of loans from the central bank, as an obligation to commercial banks, while representing a potential increase in active credit transactions (Blunden \& Thirlwell, 2013).

By obtaining funds through loans, households increase their quality of life and ability to purchase on one hand, but on the other hand, they are acquiring debt. It is usual for households to use credit to meet particular needs, especially secondary needs, in the case of delay or lack of increase in an individual's current income. Furthermore, by acquiring debt through credit, households and individual economic players support and create conditions for gradual rise in their living standards, dependent on their ability to repay such debt. By using external resources to finance their needs, households ensure the difference between satisfying their perceived needs and that which can be obtained by their current income is covered. They perceive that at the height of their current income, they would not accumulate sufficient funds to cover their current needs. Many economic players and households expect a stable income in the future and thus assume they will can repay borrowed funds. Hence their decision to deal with their needs on credit is considered acceptable, since decisions for financing current needs through loans are largely influenced by an individual's educational level, personal responsibility, and recommendations of the V4 households and individuals (Ringe \& Huber, 2015).

Customer credit allows businesses to secure payment for necessary factors that determine the development of new products, provision of services, and subsequent implementation and achievement of the desired economic effect on business. In addition, the companies' produce a positive effect by reducing tax base and thus, encourage genuine operating earnings, which generally support efficient use of all components of the company's capital and wealth. Further, the extent of credit use must be objectively justified and not cause the economy to 'overheat' and inflate. That is, customer credit needs to complement the deficit in generating financial resources and liquidity strength of businesses (Mishkin \& Eakins, 2015).

\section{Analysis of Interest Rates of Central Banks in the V4 Countries ${ }^{2}$}

The economy of the V4 countries is stimulated through expansionary monetary policy, where the development of the 'key' interest rate is reflected in the interest rates of commercial banks. The central banks in the Visegrad area can determine the short-term nominal interest rates on loans provided by

\footnotetext{
${ }^{2}$ The Visegrad Group (V4) is an alliance and a regional structure of four Central European countries - Slovak Republic, Czech Republic, Hungary and Poland, member states of the EU and NATO with the same values, a common history, culture and geographical position. V4 is a dynamic regional grouping which creates international space for strengthening coordination and consultation mechanism with a trend of finding common positions and standpoints on topical issues of foreign and European policy, regional development, economic and cultural cooperation.
} 
the commercial banks. In addition, control of key interest rates affects the level of other interest rates in the money market. Therefore, these rates influence decisions on consumption, savings, and investments, which influence the development of the economy. The central banks of the V4 countries, in terms of strategies for a monetary policy, aim to maintain an inflation target set by the zone, using the key interest rate to regulate the monetary policy. For this, Slovakia uses the rate of the main refinancing operations, the Czech Republic uses a two-week repo rate, Poland uses the reference rate, and Hungary a base rate.

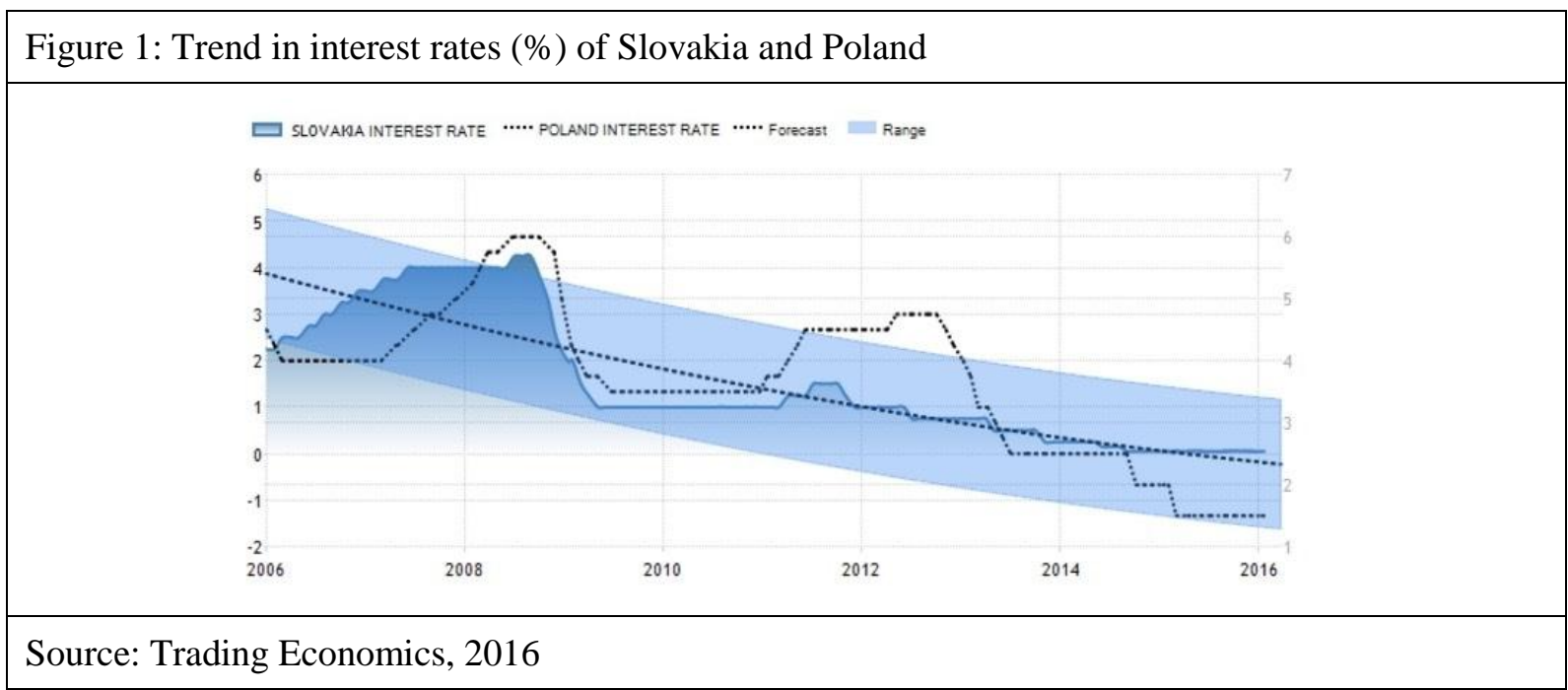

At the end of 2006, the key interest rate in Slovakia stood at 6.25\%, in the Czech Republic at 2.5\%, in Poland at $4.0 \%$, and in Hungary at $8.0 \%$ (Figures $1 \& 2$ ). In the following year, the key rates decreased in Slovakia and Hungary, and affected the availability of credit growth and bank lending. In contrast, the key interest rate increased in the Czech Republic and Poland due to inflation rising above the level of the inflation target. In 2008, all V4 countries changed their key interest rate several times in an attempt to correct the negative impacts of the global economic crisis. First, they increased rates, because of higher inflation, and then they reduced rates. This reduction was influenced by an economic and inflationary pressure slowdown. Although in Hungary, at the end of 2008, the key interest rate reached 10\%, and then 5\%, the rate decreased in other V4 countries in 2009.

Figure 2: Trend of interest rates (\%) in Hungary and the Czech Republic

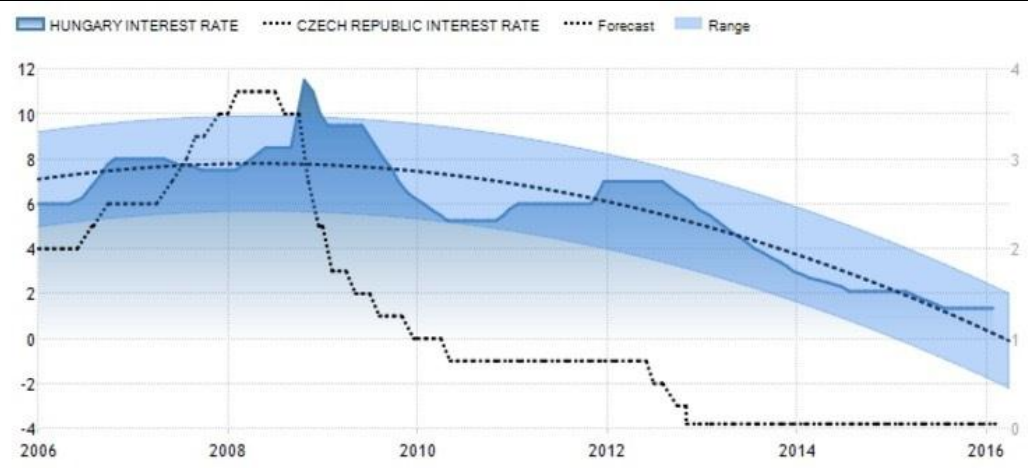

Source: Trading Economics, 2016

In Hungary, the reduction of the key interest rate in 2009 was meant to stimulate the economy and demand, which was weak at the time. The Hungarian National Bank decided to introduce new lending instruments. Slovakia adopted the Euro in 2009, and became part of the Eurozone, and thus, their interest rates were determined by the European Central Bank (ECB) that year. Their key interest rate was reduced to $1 \%$. In 2010, the key interest rate remained untouched in the V4 countries, except for mild fluctuations in Hungary. In the following year, the key interest rate in the V4 countries rose, except in the Czech Republic. In Slovakia, the increase was influenced by increase in price pressures. 
However, due to the dampening of economic recovery, interest rates were reduced to the 2010 level. In 2013, the key interest rate in Slovakia was $0.75 \%$, in the Czech Republic 0.50\%, and in Poland $4.25 \%$. These rates were not adjusted in that year. In Hungary, the rate was reduced by $1.25 \%$ to $5.75 \%$ in 2013. In 2014-2015, the rates decreased to the lowest level recorded, due to an expected period of low inflation and after growth of around $2 \%$, with the monetary policy remaining at this level. In Slovakia, the level of the key rate was $0.25 \%$, in the Czech Republic $0.05 \%$, in Poland $2.50 \%$, and in Hungary $3.00 \%$. The interest rate in Slovakia and the Czech Republic was projected to be $0.05 \%$, in Hungary $1.35 \%$, and in Poland $1.50 \%$, by the end of the first quarter of 2016. In the long-term, for 2020, the Slovakia and the Czech Republic interest rates are projected to trend around $0.50 \%$, in Hungary this is around $2.25 \%$, and in Poland around $2.00 \%$, according to global macro models of Trading Economics and analysts' expectations.

\section{Analysis of Customer Credit in Slovakia and Poland}

Slovenská sporitel'ňa is considered to be the largest bank in Slovakia, having the greatest market share and volume of consumer loans. Consumer credit provides for client's unexpected life situations, the reconstruction of an apartment or a house, buying a car, or other financial needs. Individuals typically quality for credit between the ages of 18 and 65 years. Loans are provided to either Slovak citizens or foreign nationals with permanent residence in the Slovak Republic. The parameters include loan repayment periods of 1 to 10 years, fixed interest rates, and a granted amount from $€ 300$ to $€ 25,000$. The loan can be obtained without collateral, a guarantor, or documentation of the funds intended usage (Slovenská sporitel'ňa, 2016). In Poland, the largest bank is mBank, and consumer credit is defined as loans provided under credit arrangements and consumer credit rules and conditions. Cash loans can be used for customer plans, holidays, buying consumer electronics, and reconstructing and consolidating loans, and are provided to individuals aged over 18 years (mBank, 2016).

In Poland, the individual must be a resident (a person who resides in Poland, or with temporary stays longer than three months). The parameters for consumer credit include a repayment period from three to 84 months and a variable interest rate (fixed fee and the Warsaw Interbank offered three-month rate; WIBOR $3 \mathrm{M}$ ) for loans of 500 to 150,000 zlotys. A loan can be obtained without collateral or guarantor. Consumer credit does not require documentation of fund usage and all legal requirements between the bank and the client is included in the general terms or governed by specific business conditions that are issued for individual products and services provided by banks. Leases are classified as part of the consumer credit and are provided for loans from 300 to 20,000 zlotys and that reach maturity at between three and 36 months.

Consumer credit in Slovakia was reported by the National Bank of Slovakia. The development of the economic environment in Slovakia in 2006 created favorable conditions for employment growth and improved purchasing power, and thus increased lending for consumers. The average lending rate of commercial banks for consumer loans was around $12.98 \%$ p.a. This was affected by conditions created by banks for the development of credit products. In 2008, loan portfolios were restructured and interest rates decreased. The global crisis affected the demand for loans in Slovakia, and banks, due to the financial crisis, tightened their standards on lending. Return of funds was especially important at that time. A significant decline in consumer loans in 2009 caused negative economic development. Despite the interest rate on consumer loans, which stood at $12.39 \%$ p.a., households avoided the risk of further borrowing (National Bank of Slovakia, 2016).

A weakened loan demand, lack of players for loans, and the inability to repay loans, resulted from a rise in the unemployment rate, and the slowing down of average wage growth. In the following years, the demand for loans was affected by macroeconomic indicators, namely, household income and changes in lending. The volume of loans fell drastically in 2009. The development in the volume of consumer loans was evident in the following years with increase in consumer loans affected by the financial crisis. In addition, different developments in lending were evident for short- and long-term loans, with customers preferring long-term loans, i.e., over five years. Also, the development of interest rates was influenced by the economy of Slovakia, where the interest rate on consumer loans was from $12.10 \%$ p.a. to $14.21 \%$ p.a. Consumer credit in Slovakia increased to $€ 4,747$ million at the end of 2015 from $€ 4,711$ million in the previous 2015 quarter. As a result, consumer credit averaged $€ 2,697$ million from 2006 to 2015 , reaching an unsurpassed high of $€ 4,747$ million at the end of 2015 and a record low of $€ 987$ million in the first quarter of 2006. 


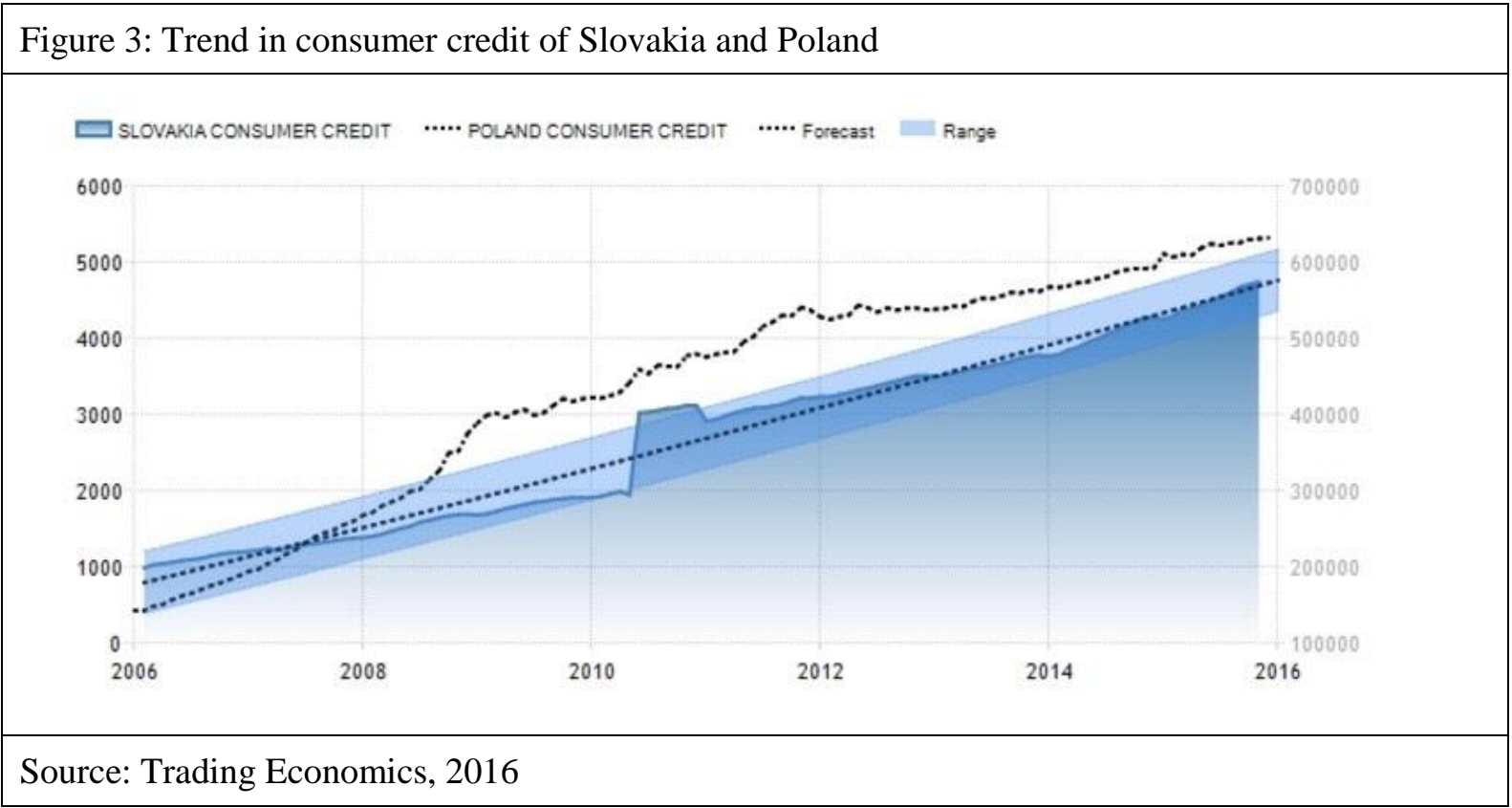

Consumer credit in Poland was reported by the National Bank of Poland (2016). A growing trend of lending in Poland remained until 2009, when the situation in the financial sector, especially banking, was affected by the financial crisis, which was subsequently reflected in the reduced volume of loans. The interest rate on consumer loans was $14.43 \%$ p.a. and banks began tightening conditions for granting loans. In 2012, there was another decrease in the volume of lending. Short-term loans, within one year, stood at a total volume of 28,500 million zlotys and long-term loans, greater than five years, stood at a total volume of 49,000 million zlotys. A significant decline in consumer loans was affected by negative economic developments and a reluctance by households to borrow. The interest rate in 2010 stood at $13.69 \%$ p.a. and the weakened demand was due to an increase in the unemployment rate. The volume in lending was significantly unchanged and approximately remained at the same level until 2013, while the interest rate between the years 2006 and 2013 rose from $11.96 \%$ p.a. to $14.66 \%$ p.a. Consumer credit in Poland had increased to 632,551 million zlotys at the end of 2015 from 631,594 million zlotys in the previous 2015 quarter, while consumer credit averaged 263,089 million zlotys up until 2015 (Trading Economics, National Bank of Poland, 2016).

Analysis of Customer Credit in Hungary and the Czech Republic

The OTP Bank of Hungary belongs among the largest banks in the country and has a market share with total assets and deposits among the largest in the country. Consumer credit in Hungary involves loans through which customers can buy equipment for their home, purchase a car, or buy whatever suits their needs. Credit is provided to individuals between the ages of 21 and 70 years. The loans are approved for either Hungarian citizens or foreign nationals with permanent residence in the country. The parameters include a loan repayment period of 13 to 84 months, fixed interest rates, and a loan from 100 to 5,000,000 forints. Furthermore, the client must be employed for at least six months and have an acceptable income. The loan can be obtained without collateral and does not require documentation of the intended use of funds.

Česká spořitelna ranks among the largest banks in the Czech Republic and consumer loans are defined as loans through which customers can buy equipment for their home, car, or any goods or services they require. Loans are provided to individuals between the ages of 18 and 65 years. Loans are approved for either Czech citizens or foreign nationals with permanent residence in the Czech Republic. The parameters include a loan repayment period of one to seven years, fixed interest rates, and loan amounts from 20,000 to 600,000 korunas. Furthermore, loans can be obtained without collateral (guarantor). With consumer loans up to 300,000 korunas, the signature of any spouse relating to the loan contract is not required. The loan can be obtained without collateral, and does not require documentation of the intended use of funds. Any legal relationship between the bank and the 
client is included in the general terms or is governed by specific business conditions issued for individual products and services provided by the bank (Česká spořitelna, 2016).

Consumer credit in Hungary was reported by the Central Bank of Hungary. The volume of loans in Hungary had upward growth and the interest rate on consumer loans stood at $18.38 \%$ p.a. until 2009 , when the volume of consumer loans began to decline. At that time, Hungary began to show a much higher degree of debt compared with other V4 countries. This deteriorated the credit conditions and banks initiated more stringent conditions and arrangements for loans. The interest rate on consumer credit was reduced by $4.00 \%$ to $15.34 \%$ p.a. By mid-2011, a declining volume of loans stopped with the total volume of loans at 34,000 billion forints for short-term loans and 45,000 billion forints for long-term loans, i.e., over five years. The following years displayed a return of decreased lending to consumers. The interest rate between 2006 and 2013 rose from $15.34 \%$ p.a. to $19.96 \%$ p.a. Consumer credit in Hungary decreased to 330 billion forints at the end of 2015, from 331 billion forints recorded in the preceding 2015 quarter. Consumer credit in Hungary averaged 460 billion forints from 2004 until 2015, reaching an all-time high of 676 billion forints in the first quarter of 2009, and a record low of 308 billion forints in the second quarter of 2015 (Central Bank of Hungary, 2016).

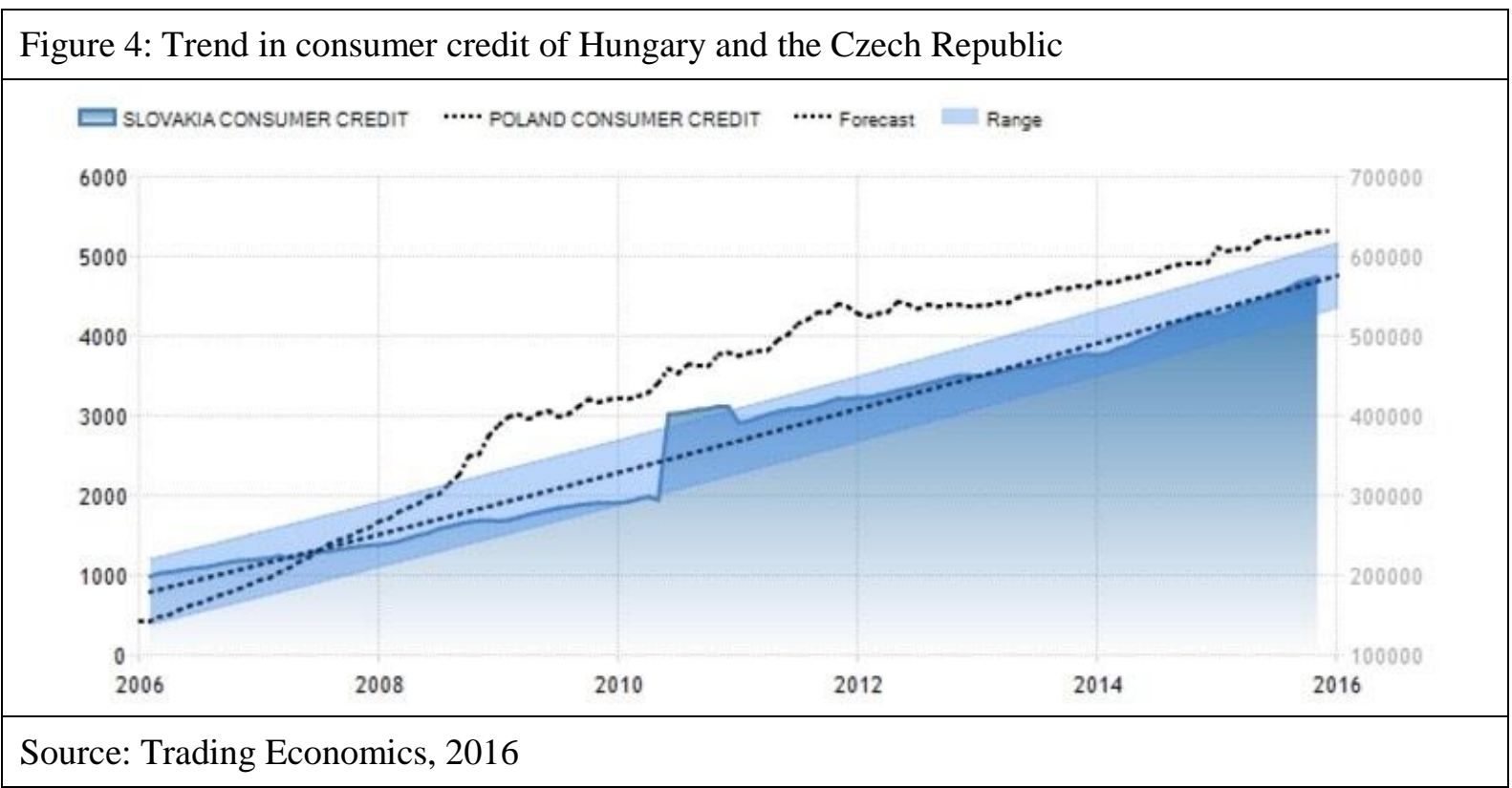

Consumer credit in the Czech Republic was reported by the Czech National Bank (2016). The growth in the volume of consumer loans in the Czech Republic was mainly influenced by monetary dynamics. In 2008, the volume of consumer loans continued to increase and the interest rate on consumer loans stood at $13.43 \%$ p.a. Impacts of the global crisis started to appear at the beginning of 2009 , with a reduction in demand for loans. Economic growth was affected by consumption, which was notably reflected in the economy of 2010, with slightly lower volumes of consumer loans. This was caused by a tightening of credit conditions, uncertainty in the labor market, and cautious households. In 2011 there was a revival of economic activity, which had a positive impact on household lending. Furthermore, loan demand was affected by interest rate, which stood at $13.94 \%$ p.a. Household consumption growth in upcoming years was supported by household income, and this positively affected the labor market. After recovery in 2013, the volume of short-term loans stood at 315,000 million korunas and that of long-term consumer loans 149,000 million koruna. The interest rate on consumer credit stood between $12.36 \%$ p.a. and $14.68 \%$ p.a. Consumer credit in the Czech Republic had increased to 1,332,365 million korunas at the end of 2015, from 1,321,432 million korunas in the previous 2015 quarter. Consumer credit in the Czech Republic had averaged 507,285 million korunas until 2015, and reached an all-time high of 1,332,365 million korunas in the last quarter of 2015 (Trading Economics, Czech National Bank, 2016). 


\section{Conclusion}

All Visegrad countries joined the European Union in 2004 and upon entering committed to accepting the Euro as a part of the convergence. However, the Slovak Republic remains the only country among the V4 countries in 2016 using the Euro. By this undertaking, Slovakia has relinquished its independent monetary policy and ceded competence to the hands of the European Central Bank. In some analysts' opinion, this step may have disadvantaged Slovakia compared to other countries of the Visegrad Group, when considering the possibility of using economic instruments, policies in correcting and guiding economic development, and ensuring macroeconomic stability, with fiscal policy attaching great importance to stabilizing fluctuations in the economic cycle. This paper focused on consumer credit in the V4 countries, to assess the countries' development since 2006, by outlining aspects and problems due to the economic recovery. Based on this review the V4 countries have not avoided the negative impact of the financial and economic crisis; the crisis increased the concerns of borrowers and banks, and this resulted in banks considering possible measures in the consumer credit line to avoid potential risks. Screening and analyzing available data showed that the economic situation in the consumer credit market improved after the financial crisis because of various state stabilization measures. Introducing optimal conditions has had a positive impact on economic development in the V4 countries in terms of consumption, which positively influenced the increase in consumer loans.

Short- and long-term generation, allocation, and lending during 2006-2015 was mostly affected by cyclical economic developments. Following the recovery, international markets and, subsequently, the V4 markets, have created conditions for accelerating the economic regeneration of the credit market, which has significantly contributed to economic growth for the V4 economies. Economic growth was, and remains, one of the most important objectives for convergence of the Central European region after the period of crisis. Each country sought to achieve economic growth by influencing its credit policy, without which their economies would partially have stagnated, with negative impacts and implications for their populations, regarding their quality of life or financial resources. The specific advantages of consumer credit in the markets of the V4 countries provided instant gratification without the need for longer saving, the opportunity to receive financial resources in a relatively simple and quick manner, and payment in several smaller outgoings, which do not burden the household budget as would a larger one-time payment. Overall, economic growth was affected by the amount and conditions of consumer credit in the economy, and this acted as a catalyst for economic growth in the V4 countries. In this case, higher credit amounts transformed into greater long-term economic growth, thereby achieving the ability of Visegrad countries to provide diverse economic goods and services for their populations.

\section{References}

Blunden, T., \& Thirlwell, J. (2013). Mastering Operational Risk. London: Prentice Hall, 376.

Bruun, N. (2014). The Economic and Financial Crisis in Europe. Oxford: Hart Publishing, 384.

Central Bank of Hungary. (2016). Statistical data. Available 06.02.2016, at https://www.mnb.hu/.

Czech National Bank. (2016). Statistical data. Available 06.02.2016, at https://www.cnb.cz/en/.

Česká Spořitelna. (2016). Statistical data. Available 06.02.2016, at http://www.csas.cz/.

mbank. (2016). Statistical data. Available 06.02.2016, at https://www.mbank.pl/indywidualny/.

Mishkin, F., \& Eakins, S. (2015). Financial Markets and Institutions, Global Edition. London: Prentice Hall, 704.

Mishkin, F., Giuliodori, M., \& Matthews, K. (2013). The Economics of Money, Banking and Financial Markets. London: Prentice Hall, 656.

National Bank of Poland. (2016). Statistical data. Available 06.02.2016, at http://www.nbp.pl/.

National Bank of Slovakia. (2016). Statistical data. Available 06.02.2016, at http://www.nbs.sk/en/home/.

Ringe, W., \& Huber, P. (2015). Challenges in the Global Financial Crisis. Oxford: Hart Publishing, 288.

Slovenská sporitel'ňa. (2016). Statistical data. Available 06.02.2016, at https://www.slsp.sk/.

Trading Economics. (2016). Statistical data. Available 06.02.2016, at http://www.tradingeconomics.com/. 